\title{
Antibacterial activity of nifuratel in urine and serum
}

\author{
J. McGEACHIE, G. ROBINSON, AND D. BLACK \\ From the University Department of Bacteriology, Glasgow Royal Infirmary, Glasgow
}

SYNOPSIS The minimum inhibitory concentrations of nifuratel for 205 randomly selected isolates from urinary tract infections were tested by tube dilution. Of these, $177(86.3 \%)$ were resistant to more than $6 \mu \mathrm{g} / \mathrm{ml}$ and 140 of $141(99.3 \%)$ strains of Escherichia coli were resistant to more than $3 \mu \mathrm{g} / \mathrm{ml}$. Urine levels of nifuratel were examined in two groups: one group had $400 \mathrm{mg}$ given once and the other group had $2 \mathrm{~g}$ given over 24 hours. In both groups samples of urine were collected every hour for seven hours after the last dose. After one 400-mg dose the maximum urine level achieved by any subject was $2.0 \mu \mathrm{g} / \mathrm{ml}$ and the mean maximum level was $0.75 \mu \mathrm{g} / \mathrm{ml}$. With the $2 \mathrm{~g}$ total dose, the maximum level noted was $4 \mu \mathrm{g} / \mathrm{ml}$ and the mean maximum level was $1.8 \mu \mathrm{g} / \mathrm{ml}$. No measurable inhibition was noted in any of the blood samples removed at one and a half to two hours after the last dose.

Nifuratel (Magmilor) is a furan derivative, the chemical description of which is $\mathrm{N}$-(5-nitro-2-furfurylidene) - 3 - amino - 5 - methylmercaptomethyl - 2oxadolidinone. It has been used mainly in the treatment of vulvo-vaginal infections, but has also been recommended for the treatment of urinary infections (Coppi and Bertagnolli, 1965; Tynan, Macis, and Ward-McQuaid, 1969). In view of the unfortunate controversy over another 5-nitrofuran, namely, Furaltdone, it was considered essential to find if the oral administration could achieve significant inhibitory levels in the urine. The minimum inhibitory concentrations of nifuratel for a sample of strains isolated from proven cases of urinary tract infections would be used to indicate the significance of the level in the urine.

\section{Materials and Methods}

\section{ORGANISMS}

The minimum inhibitory concentration (MIC) of nifuratel was tested with 205 strains which were isolated from patients with pyuria and bacteriuria. There were 141 strains of Escherichia coli, 29 strains of Proteus mirabilis, 20 strains of Klebsiella/Aerobacter species, seven of coagulase-negative Staphylococcus albus, four of Streptococcus faecalis, and two strains each of Staphylococcus aureus and Pseudomonas aeruginosa.

NIFURATEL SOLUTIONS

The stock concentration of nifuratel was prepared Received for publication 21 October 1971. by dissolving $0.1 \mathrm{~g}$ in $10 \mathrm{ml}$ dimethylformamide (Analar); this was kept in the dark and at $4^{\circ} \mathrm{C}$ for not more than five days then discarded. The working standards were prepared daily by diluting with quarter-strength Ringer's solution (Oxoid) to a concentration of $50 \mu \mathrm{g} / \mathrm{ml}$. The tube sensitivities for the MIC used the strongest concentration of $25 \mu \mathrm{g} / \mathrm{ml}$ with doubling dilutions to $0 \cdot 1 \mu \mathrm{g} / \mathrm{ml}$.

\section{ASSAY OF NIFURATEL IN URINE}

Two groups were studied. In the first group there were 11 normal male subjects each of whom received $400 \mathrm{mg}$ of nifuratel once after breakfast. In the second group of eight normal male subjects, each received $400 \mathrm{mg}$ at four-hourly intervals on the first day followed by $400 \mathrm{mg}$ after breakfast on the second day, a total of $2 \mathrm{~g}$ nifuratel in 24 hours.

In the first group a specimen of urine was taken before administration of the drug to act as a baseline. In both groups urine was collected every hour for seven hours after the administration of the last dose of the drug. The fluid intake in both groups was unrestricted. In subjects in the first group, blood samples were removed for assay before and one and a half hours after ingestion of the drug. The assays were performed on the serum by tube dilution.

As a control of the methods, a similar series of assays was made following a single dose of $250 \mathrm{mg}$ ampicillin.

METHOD OF ASSAY

In separate series of experiments it had been found that Seitz filtration of nifuratel solution in urine 
resulted in a significant decrease in measurable inhibition of the indicator organism. On the other hand exposure to $60^{\circ} \mathrm{C}$ in a water bath up toone hour did not affect the potency significantly. As a routine all specimens of urine were treated by exposure to $60 \mathrm{C}$ for 30 minutes to sterilize them. Doubling dilutions of urine in quarter-strength Ringer's solution (Oxoid) were made from a neat aliquot in the first tube to a dilution of 256. The indicator organism was a coagulase-negative Staphylococcus albus with a MIC of $0.5 \mu \mathrm{g} / \mathrm{ml}$; one drop of $1: 100$ dilution of an overnight culture was added to each tube. Sterility controls of the urine both before and after sterilization were included. As an indication of the bactericidal effect, the last three tubes to show

\begin{tabular}{|c|c|c|c|c|c|c|c|c|}
\hline \multirow[t]{2}{*}{ Strain } & \multicolumn{3}{|c|}{$M I C(\mu \mathrm{g} m l)$} & \multirow[b]{2}{*}{0} & \multirow[b]{2}{*}{3} & \multirow[b]{2}{*}{1.5} & \multirow[b]{2}{*}{ (1) -5} & \\
\hline & 25 & 525 & 12 & & & & & \\
\hline Escherichia coli & 42 & 3 & 75 & 20 & 1 & - & & 141 \\
\hline Proteus mirabilis & 24 & 1 & 4 & & & & & 29 \\
\hline Klebsiella terobacterspp. & 16 & 2 & 2 & & & & & 20 \\
\hline Strep faecalis & 2 & 1 & 1 & - & & - & $\cdots$ & 4 \\
\hline Staph. albus & & & 1 & 1 & 1 & 3 & 1 & 7 \\
\hline Staph. aureus & - & 1 & & & 1 & & -- & 2 \\
\hline Ps. aeruginosa & 2 & - & & & & $\ldots$ & & 2 \\
\hline Total & 86 & 8 & 83 & 21 & 3 & 3 & 1 & 205 \\
\hline
\end{tabular}

Table I MIC of $2(1) 5$ strains

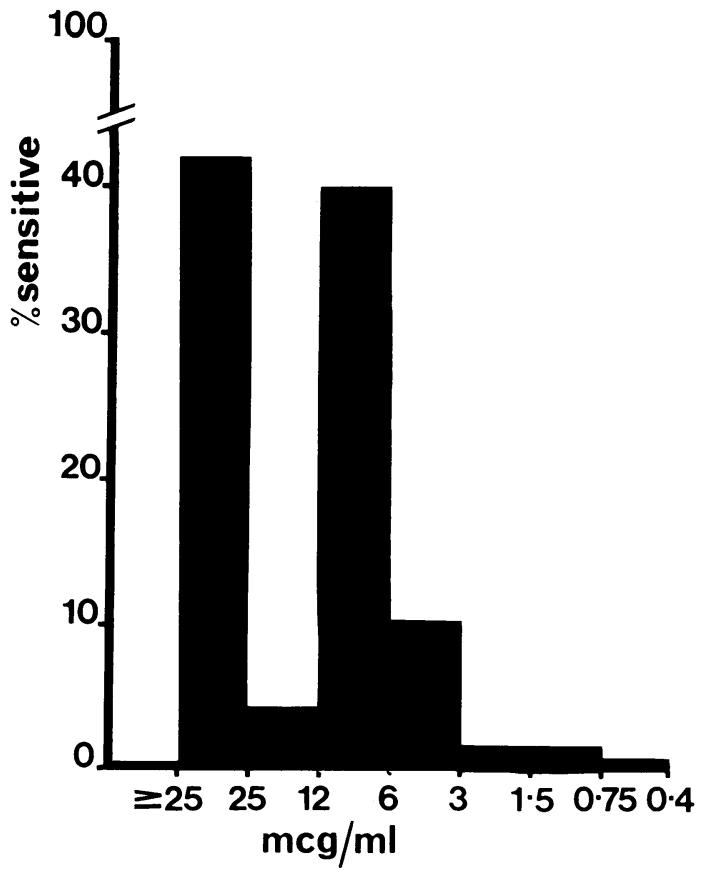

Fig. 1 Minimum inhibitory concentration of nifuratel in 205 isolates. inhibition of the indicator organisms were subcultured on to nutrient agar.

\section{Results}

SENSITIVITY OF URINARY ISOLATES

TO NIFURATEL

The MIC of the 205 strains are shown in Table I and Figure 1. The strains of Escherichia coli were all resistant to $1.5 \mu \mathrm{g} / \mathrm{ml}$; indeed 140 of the $141\left(99 \cdot 3^{\circ}{ }_{0}\right) \vec{\circ}$ were resistant to $3 \mu \mathrm{g} / \mathrm{ml}$ or more. Only the strains of coagulase-negative Staphylococcus albus showed a marked sensitivity to nifuratel; five of the seven isolates were sensitive to less than $3 \mu \mathrm{g} / \mathrm{ml}$. The collective MIC of all the strains is shown in Fig. 1: 177 of the 205 strains $\left(86 \cdot 3^{\circ}\right)$ were resistant to more than $6 \mu \mathrm{g} / \mathrm{ml}$.

\section{CONCENTRATIONS OF NIFURATEL IN THE} URINE

After one dose of $400 \mathrm{mg}$

The maximum concentration found was $2.0 \mu \mathrm{g} / \mathrm{ml}$. which occurred in three subjects within the first three hours (Table II). The maximum mean concentration was $0.75 \mu \mathrm{g} / \mathrm{ml}$ which occurred at approximately two hours after the start of the experiment (Figure 2).

\begin{tabular}{|c|c|c|c|c|}
\hline \multirow[t]{2}{*}{$\begin{array}{l}\text { Hours after Last } \\
\text { Dose }\end{array}$} & \multicolumn{2}{|l|}{$4(1) \mathrm{mg}$} & \multicolumn{2}{|l|}{$\therefore g$} \\
\hline & $\begin{array}{l}\text { Range } \\
(\mu \mathrm{g} m l)\end{array}$ & Mean & $\begin{array}{l}\text { Range } \\
(\mu g m l)\end{array}$ & Me'an \\
\hline 1 & $0 \cdot 0-2 \cdot 0$ & 0.50 & $0 \cdot 5-4 \cdot 0$ & 180 \\
\hline 2 & $0 \cdot 0-2 \cdot 0$ & 0.75 & $0 \cdot 0-4 \cdot 0$ & $1 \cdot 80$ \\
\hline 3 & $0 \cdot 0-20$ & 0.40 & $0 \cdot 5-2 \cdot 0$ & $1 \cdot 10$ \\
\hline 4 & $0 \cdot 0-1 \cdot 0$ & 030 & $0 \cdot 5-2 \cdot 0$ & $0 \cdot 80$ \\
\hline 5 & $0 \cdot 1-1 \cdot 0$ & 010 & $0 \cdot 0-2 \cdot 0$ & 0.50 \\
\hline 6 & $0 \cdot 0-0.5$ & 0.20 & $0 \cdot 0-1 \cdot 0$ & $0 \cdot 30$ \\
\hline 7 & $0 \cdot 0-1 \cdot 0$ & 0.40 & $0.0 .2 \cdot 0$ & $0 \cdot 40$ \\
\hline
\end{tabular}

Table II Concentrations of nifuratel in urine

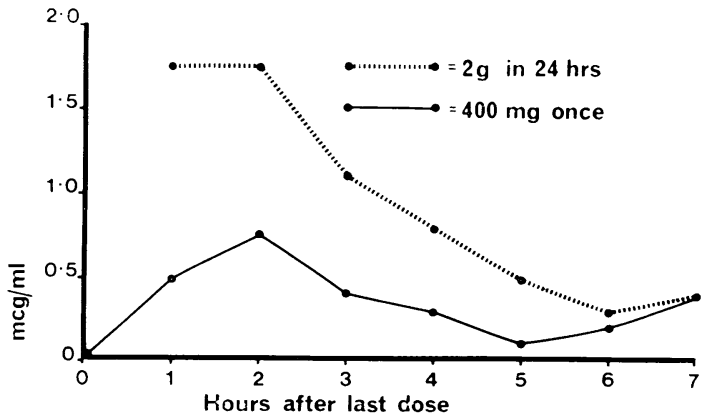

Fig. 2 Concentration of nifuratel in urine. 


\section{After $2 \mathrm{~g}$ in 24 hours}

The maximum concentration was found to be $4 \mu \mathrm{g} / \mathrm{ml}$ which occurred in two subjects within the first two hours after the last dose. The maximum mean concentration was $1.8 \mu \mathrm{g} / \mathrm{ml}$ at one to two hours after the last dose.

\section{Bacteriostatic and bactericidal levels}

In those specimens which showed inhibition, approximately $70 \%$ showed a difference of one tube dilution between the bacteriostatic concentration and that giving a bactericidal effect; the rest had identical activity.

Comparison of the concentrations of nifuratel and ampicillin in the urine

The levels of nifuratel and ampicillin are shown in Table III. The comparisons were made over a sixhour period.

\begin{tabular}{clc}
\hline $\begin{array}{c}\text { Hours after } \\
\text { Last Dose }\end{array}$ & $\begin{array}{l}400 \mathrm{mg} \\
\text { Nifuratel }\end{array}$ & $\begin{array}{c}250 \mathrm{mg} \\
\text { Ampicillin }\end{array}$ \\
\hline 1 & $0 \cdot 50$ & $76 \cdot 8$ \\
2 & $0 \cdot 75$ & 307.2 \\
3 & $0 \cdot 40$ & $307 \cdot 2$ \\
4 & $0 \cdot 30$ & $153 \cdot 6$ \\
5 & $0 \cdot 10$ & $76 \cdot 8$ \\
6 & $0 \cdot 20$ & 38.4 \\
\hline
\end{tabular}

Table III Comparison of the concentrations $(\mu \mathrm{g} / \mathrm{ml})$ of nifuratel and ampicillin in urine

\section{Blood levels of nifuratel}

Only one postadministration assay on blood samples was prepared from each subject. None of the specimens removed between one and a half and two hours after ingestion of $400 \mathrm{mg}$ nifuratel revealed any inhibition of the indicator. A similar assay of the blood from the subject on ampicillin gave an inhibition level of $2.4 \mu \mathrm{g} / \mathrm{ml}$ serum.

\section{Discussion}

Nitrofurans have been used for the treatment of urinary tract infections for nearly two decades, since Sweetser and Harrison (1951) used a dilute solution of nitrofurazone to irrigate the bladder. Nitrofurantoin has achieved a greater impact on the treatment of urinary infections and has been widely used since the reports of Norfleet, Beamer, and Carpenter (1952) and of Mintzer, Kadison, Shlaes, and Felsenfeld (1953). Another 5-nitrofuran which was considered to be of use in several clinical situations was furaltadone. However, subsequent clinical and laboratory evaluation of the compound revealed it to be of doubtful efficacy (McCarthy and Finland, 1961 ; Lancet, 1961).

In our study of the effect in vitro of nifuratel on urinary pathogens we have found that most had an MIC of more than $3 \mu \mathrm{g} / \mathrm{ml}$ as measured by tube culture inhibition. This level of nifuratel was not obtained by any of the subjects who received a single dose of $400 \mathrm{mg}$ nifuratel. The mean maximum level was less than $1 \mu \mathrm{g} / \mathrm{ml}$, and only three subjects achieved a level of $2.0 \mu \mathrm{g} / \mathrm{ml}$. After $2 \mathrm{~g}$ nifuratel in a 24-hour period the maximum level produced by two subjects was $4 \mu \mathrm{g} / \mathrm{ml}$ but the mean maximum level was below $2 \mu \mathrm{g} / \mathrm{ml}(1.8 \mu \mathrm{g} / \mathrm{ml})$.

In none of the subjects was a measurable level of inhibition achieved in serum. A comparable assay performed on the serum from the subject who had received $250 \mathrm{mg}$ of ampicillin gave a level of $2 \cdot 4 \mu \mathrm{g} / \mathrm{ml}$.

We wish to thank Messrs Calmic Ltd, Crewe, for the supply of nifuratel (Magmilor) as tablets and as powder for standard controls. We are also indebted to $\mathrm{Mr}$ T. Parker for the photographs.

\section{References}

Coppi, F., and Bertagnolli, V. (1965). Esperienze cliniche in urologia con il metilmercadone nurovo chemioterapico furanico. Urologia (Treviso), 32, 678-683.

Lancet (1961). Annotation. Furaltadone. Lancet, 2, 357.

McCarthy, C. G., and Finland, M. (1961). Furaltadone: antibacterial activity in vitro and in serum of patients during treatment. Arch. intern. Med., 107, 863-871.

Mintzer, S., Kadison, E. R., Shlaes, W. H., and Felsenfeld, O. (1953). Treatment of urinary tract infection with a new antibacterial nitrofuran. Antibiot. and Chemother., 3, 151-157.

Norflect, C. M., Jr., Beamer, P. R., and Carpenter, H. M. (1952). Furadantin in infections of the genito-urinary tract. Trans. S.-east Sect. Amer. urol. Ass., 26-34.

Sweetser, T. H., Jr., and Harrison, C. H. Jr. (1951). Nitrofurazone in the treatment of urethro-trigonitis. J. Urol., 65, 684-687.

Tynan, A. P., Macis, F. R., and Ward-McQuaid, J. N. (1969) Nifuratel in urinary infections. Brit. J. Urol., 41, 271-279. 